\title{
Webinar Penyegaran Kader Posyandu; Update Isu dan Penanganan Masalah Gizi di Wilayah Kerja Desa Cibanteng Bogor
}

\author{
Tri Ardianti Khasanah ${ }^{1}$, Mia Srimiati ${ }^{2}$, Dea Tiany Violeta ${ }^{3}$, Maria Chitrawari ${ }^{4}$ \\ ${ }^{1-4}$ Fakultas Ilmu Kesehatan dan Teknologi, Universitas Binawan \\ Email:ardianti@binawan.ac.id
}

Submitted : 10/10/2021

Accepted: 08/01/2022

Published: 28/01/2022

\begin{abstract}
Posyandu is the spearhead and one of the community-based health efforts that has an important role in bringing promotive and preventive efforts closer to the community, especially efforts to improve the nutritional status of the community and maternal and child health. The achievement of monitoring growth in 2018 in Cibanteng Village was 76.5\% with a target of 80\%, in connection with these conditions it was deemed necessary to equalize perceptions and increase the ability/skills of posyandu cadres, especially the management of posyandu and posyandu cadres in the working area. The purpose of this community service is to provide refreshment and understanding of the main tasks of cadres in managing and carrying out minimal activities at posyandu. The target in this community service is the cadres of the Cibanteng Village working area. The results of community service indicate that the refresher for cadres in the Cibanteng Bogor Village Work Area has been going well, the interest and enthusiasm of the cadres are fully willing to carry out refresher knowledge, the implementation of the refresher is in accordance with the training objectives. The drawback is that the learning method in the implementation of the refresher is still relatively new and difficult for village cadres to understand, namely using the zoom webinar media.
\end{abstract}

Keywords: kader, nutritional status, posyandu

\begin{abstract}
Abstrak
Posyandu merupakan ujung tombak dan salah satu upaya kesehatan yang berbasis masyarakat yang memiliki peran penting dalam mendekatkan upaya promotif dan preventif kepada masyarakat, terutama upaya peningkatan status gizi masyarakat serta kesehatan ibu dan anak. Capaian pemantauan pertumbuhan pada tahun 2018 di Desa Cibanteng yaitu sebesar 76.5\% dengan target $80 \%$, sehubungan dengan kondisi tersebut dirasa perlu penyamaan persepsi dan peningkatan kemampuan / keterampilan kader posyandu terutama pengelolaan posyandu dan kader posyandu di wilayah kerja tersebut. Tujuan pengabmas ini ialah memberi penyegaran kembali dan pemahaman tugas-tugas pokok kader dalam mengelola dan melaksanan kegiatan minimal di posyandu. Sasaran dalam pengabmas ini adalah kader wilayah kerja Desa Cibanteng. Hasil pengabdian masyarakat menunjukkan bahwa penyegaran kepada kader di Wilayah Kerja Desa Cibanteng Bogor ini sudah berjalan dengan baik, minat dan antusias kader sudah sepenuhnya ingin melaksanakan penyegaran ilmu, pelaksanaan penyegaran sesuai dengan tujuan pelatihan. Adapun kekurangannya yaitu metode pembelajaran dalam pelaksanaan penyegaran masih dibilang baru dan sulit dipahami oleh kader desa yaitu menggunakan media webinar zoom.
\end{abstract}

Kata Kunci: kader, posyandu, status gizi

\section{PENDAHULUAN}

Pembangunan sektor kesehatan di Indonesia diarahkan untuk memperluas jangkauan dan meningkatkan mutu pelayanan kesehatan dasar utama bagi ibu dan anak. Salah satu bentuk kegiatan untuk memperluas jangkauan dan meningkatkan mutu pelayan kesehatan adalah posyandu (Bappenas, 2018). Posyandu merupakan ujung tombak dan salah satu upaya kesehatan yang berbasis masyarakat yang memiliki peran penting dalam mendekatkan upaya promotif dan preventif kepada masyarakat, terutama terkait dengan upaya 
peningkatan status gizi masyarakat serta kesehatan ibu dan anak. Menurut Kemenkes (2011), Pelayanan Posyandu untuk bayi dan anak balita harus dilaksanakan secara menyenangkan dan memacu kreativitas tumbuh kembangnya.

Jenis pelayanan yang diselenggarakan Posyandu untuk balita mencakup: Penimbangan berat badan dan pengukuran panjang badan/tinggi badan, penentuan status pertumbuhan menggunakan KMS, penyuluhan dan konseling. Pemantauan petumbuhuan gizi pada anak merupakan salah satu kegiatan utama program perbaikan gizi yang menitikberatkan pada upaya pencegahan dan perbaikan keadaan gizi balita (Masro, 2013).

Capaian pemantauan pertumbuhan pada tahun 2018 di Desa Cibanteng yaitu sebesar $76.5 \%$ dengan target $80 \%$, sehubungan dengan kondisi tersebut dirasa perlu penyamaan persepsi dan peningkatan kemampuan / keterampilan kader posyandu terutama pengelolaan posyandu di wilayah kerja tersebut.

Menurut Kemenkes RI, masih ditemukan banyaknya masalah antara lain, kelengkapan sarana, keterampilan kader yang belum memadai, data kader dan strata posyandu. Kinerja pelayanan kesehatan merupakan salah satu faktor penting dalam upaya peningkatan kualitas kesehatan penduduk menurut Sukiarko (2007), kurang berfungsinya posyandu disebabkan karena kemampuan kader di Posyandu yang masih rendah. Maka dari itu, sering ditemukannya penurunan kinerja posyandu, keterhambatan dalam proses penyampaian informasi dan pesan-pesan gizi, penurunan jumlah balita yang datang serta ketidak akuratan data pada proses pelaksanaan kegiatan.

Sehubungan dengan kondisi diatas dirasa perlu penyamaan persepsi dan peningkatan kemampuan / keterampilan kader posyandu terutama pengelolaan posyandu dan kader posyandu di wilayah kerja maka Kami akan menyelenggarakan pelatihan kader posyandu.

\section{TARGET DAN LUARAN}

Peserta kegiatan ini ialah kader kesehatan yang mayoritas wanita. Posyandu di wilayah kerja Desa Cibanteng ini memiliki 12 posyandu yang tersebar di beberapa titik daerah kecamatan Ciampea Bogor

Luaran dari kegiatan ini adalah publikasi kegiatan pengabdian masyarakat di Jurnal Pengabdian Masyarakat; rekaman video pembelajaran; HKI untuk rekaman video pembelajaran yang telah dibuat.

\section{METODE PELAKSANAAN}

Kegiatan webinar berisi penyuluhan yang dilaksananakan sebanyak 2 kali, yaitu pada tanggal 10 dan 17 Januari 2021 jam 10.00-12.00 WIB bertempat di Kantor Desa Cibanteng Bogor. Berikut Kerangka konsep penyulunan online (webinar) pada Kader Posyandu

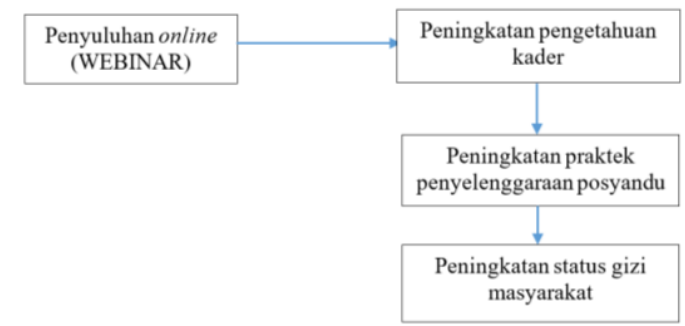

Tahapan Kegiatan Webinar :

1. Penyuluh melakukan ice breaking bersama peserta untuk mencairkan suasana

2. Penyuluh memberikan pre-test yang berupa pertanyaan seputar materi yang akan diberikan kepada peserta

3. Penyuluh dari dosen dan mahasiswa memberikan penjelasan mengenai materi "Sistem 5 Meja dan PMBA"

4. Penyuluh memberikan post test berupa pertanyaan yang sama dengan pre-test kepada peserta

5. Sesi tanya jawab antara peserta dengan penyuluh

6. Pemberian doorprize kepada peserta 


\section{HASIL DAN PEMBAHASAN}

Kegiatan pengabdian masyarakat dilaksanakan dua kali pada tanggal 10 Januari dan 17 Januari 2021 di Kantor Desa Cibanteng Bogor. Peserta kegiatan ini adalah kader kesehatan yang mayoritas wanita. Posyandu di wilayah kerja Desa Cibanteng ini memiliki 12 posyandu yang tersebar di beberapa titik daerah kecamatan Ciampea Bogor.

Kegiatan ini dilaksanakan oleh tim pengabdi sebanyak dua orang dosen Universitas Binawan yang bertindak sebagai narasumber penyuluh dan ketua pelaksana tim pengabdi, dan lima orang mahasiswa gizi alih jenjang semester lima yang membantu dosen dalam memberikan penyuluhan dan pelatihan kepada para kader. Acara pertama sebelum kegiatan penyuluhan ini dilakukan adalah memberikan pre-test untuk mengukur seberapa jauh pengetahuan para kader yang bekerja di wilayah kerja Desa Cibanteng. Pre-test ini dilakukan selama 10 menit, setelah itu mahasiswa membantu untuk mengumpulkan kertas pre-test yang telah diisi. Hari pertama pengabdian pada tanggal 10 Januari, kegiatan setelah pre-test yaitu dosen melakukan penyuluhan melalui webinar Zoom yang berisikan materi pengertian, tujuan, prinsip dan macammacam kegiatan posyandu serta identifikasi saat ditemukan balita gizi kurang yang berlangsung selama 30 menit. Mahasiswa kemudian melanjutkan penyuluhan tentang bagaimana penggunaan alat antropometri dengan pemutaran video dan praktek langsung penggunaan alat antropometri yang diikuti secara antusias oleh para kader baru maupun kader senior selama 30 menit. Setelah penyuluhan, praktek penggunaan alat, dan sesi tanya jawab selama 15 menit, peserta kader diminta kembali mengisi post-test dengan soal yang sama dengan pre-test. Harapannya untuk mengetahui apakah peserta kader memahami dan menyimak dengan baik materi yang diberikan pada hari itu.

Hari kedua pengabdian yang dilaksanakan pada 17 Januari hampir sama dengan kegiatan hari pertama. Mahasiswa yang berlaku sebagai moderator menyampaikan review materi dan kegiatan yang sudah dilakukan pada hari pertama. Pre-test untuk materi hari kedua juga sama dilakukan selama 10 menit, setelah itu dosen melakukan penyuluhan melalui webinar Zoom yang berisikan materi gizi seimbang saat pandemi Covid-19 dan dilanjutkan penyuluhan oleh mahasiswa dengan materi pemberian makan serta isu mengenai hal tabu makanan pada bayi dan anak.

Kegiatan penyuluhan hari pertama para peserta memperhatikan setiap materi penyuluhan dari dosen maupun mahasiswa dengan seksama. Terlihat saat memasuki sesi tanya jawab dan praktek penggunaan alat antropometri, hampir seluruh kader antusias dalam kegiatan hari pertama ini. Penyuluhan hari kedua para peserta juga terlihat memperhatikan setiap materi penyuluhan dari dosen maupun mahasiswa dengan seksama, hanya saja ada 4 orang peserta yang tidak bisa hadir, dengan alas an sakit dan ada keperluan pribadi yang tidak bisa ditinggalkan.

Adapun hasil pre-test dan post-test berdasarkan output dalam uji hipotesis wilcoxon test statistics, diketahui Asymp. Sig. (2-tailed) bernilai 0.095 , karena nilai 0.095 lebih besar dari 0.05 maka disimpulkan "Ha ditolak" artinya tidak ada perbedaan antara hasil penyegaran kader dalam nilai Pre-test dan Post-test pada hari pertama dan hari kedua. Terlihat pada hari kedua para kader seolah-olah malas mengisi lembar jawaban dan sangat cepat sekali dalam menjawab soal-soal yang kami berikan, hal tersebut dapat mempengaruhi uji data kami untuk pelaksanaan hari kedua; dan metode pembelajaran dalam pelaksanaan penyegaran masih dibilang 
baru dan sulit di pahami oleh kader desa yaitu menggunakan media webinar zoom dan mereka menjadi sulit berinteraksi dengan pembicara kami dikarenakan sinyal di daerah tersebut sering hilang.

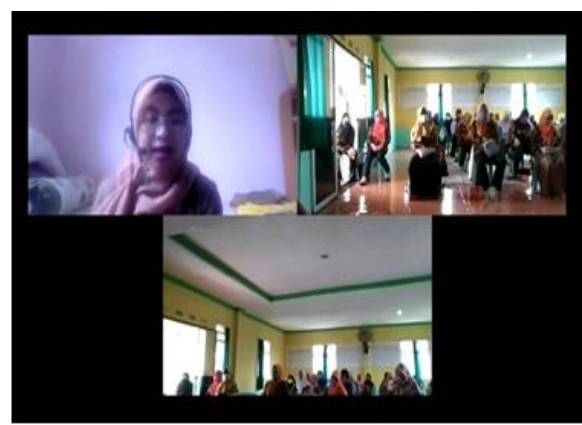

Gambar 1. Kegiatan Webinar Melalui aplikasi Zoom

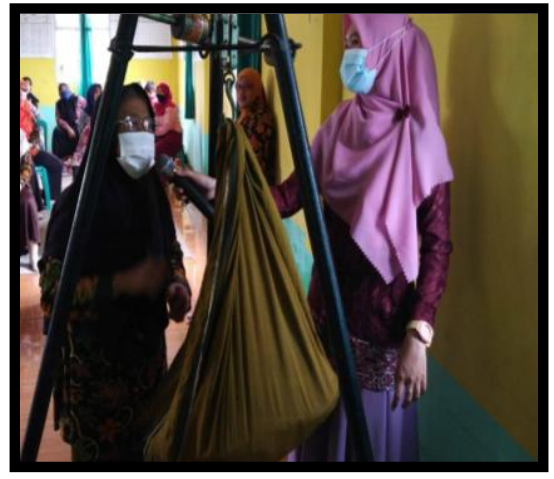

Gambar 2. Peragaan Alat Antropometri

\section{KESIMPULAN DAN SARAN \\ 1. Kesimpulan}

Kegiatan pengabdian masyarakat ini telah dilaksanakan dua kali pada tanggal 10 Januari dan 17 Januari 2021 di Kantor Desa Cibanteng Bogor dengan peserta yaitu kader kesehatan di Wilayah Kerja Desa Cibanteng Bogor.

Hasil pengabdian masyarakat ini menunjukkan bahwa penyegaran kepada kader di Wilayah Kerja Desa Cibanteng Bogor ini sudah berjalan dengan baik, minat dan antusias kader sudah sepenuhnya ingin melaksanakan penyegaran ilmu, pelaksanaan penyegaran sesuai dengan tujuan pelatihan. Adapun kekurangannya yaitu metode pembelajaran dalam pelaksanaan penyegaran masih dibilang baru dan sulit dipahami oleh kader desa yaitu menggunakan media webinar zoom.

\section{Saran}

Metode penyuluhan yang kami gunakan secara daring melalui media zoom dikarenakan risiko penularan Covid-19 untuk penyegaran kader di Wilayah Kerja Desa Cibanteng Bogor terbilang sangat baru bagi para kader dan sulit dipahami. Pelatihan dan penyegaran dengan metode luring atau secara langsung lebih diterima oleh para kader sehingga dapat meningkatkan minat dan antusias para kader dibanding dengan metode daring

\section{UCAPAN TERIMAKASIH}

Puji syukur kami panjatkan kepada Tuhan Yang Maha Esa atas segala karuniaNya dan juga keikutsertaan peserta pada kegiatan ini yang sudah cukup antusias, sehingga laporan akhir pengabdian masyarakat ini berhasil diselesaikan. Pengabdian masyarakat yang sudah dilakukan berupa: Webinar Penyegaran Kader Posyandu; Update Isu dan Penanganan Masalah Gizi di Wilayah Kerja Desa Cibanteng Bogor. Terima kasih atas peran serta tim dalam pelaksanaan acara serta pembuatan laporan akhir ini sehingga dapat diselesaikan dengan baik.

\section{DAFTAR PUSTAKA}

Bappenas. 2018. Penguatan Pelayanan Kesehatan dasar di Puskesmas. Bappenas : Jakarta

KEMENKES. 2011. Buletin Jendela Data dan Informasi Kesehatan. Jakarta: Kementrian Kesehatan RI

Masro, A. dkk. 2013. Implementasi penangguangan gizi buruk di wilayah kerja Puskesmas Sungai Limau Kabupaten Padang Pariaman. Jurnal Kesehatan Masyarakat. Vol 8. No 1. Hal 21-26.

Sukiarko E. 2007. Pengaruh pelatihan dengan metode belajar 
Jurnal Abdimas Kesehatan (JAK) Vol 4, No 1, Januari, 2022

DOI : 10.36565/jak.v4i1.275

p-ISSN: 2655-9266

e-ISSN: 2655-9218

berdasarkan masalah terhadap pengetahuan dan keterampilan kader gizi dalam kegiatan posyandu: Studi di Kecamatan Tempuran Kabupaten Magelang. JurnalKesehatan, 4 (2): 31-32 